\title{
PERBANDINGAN PENURUNAN KONSOLIDASI PADA TANAH YANG BELUM DIPERBAIKI SERTA YANG DIPERBAIKI DENGAN PRELOADING DAN PEMANCANGAN KELILING
}

\author{
Wilson $^{1}$ dan Alfred Jonathan Susilo² \\ ${ }^{1}$ Program Studi Sarjana Teknik Sipil, Universitas Tarumanagara, Jl. Letjen S. Parman No.1 Jakarta \\ Email:wilsonzhouu94@gmail.com \\ ${ }^{2}$ Program Studi Sarjana Teknik Sipil, Universitas Tarumanagara, Jl. Letjen S. Parman No.1 Jakarta \\ Email: alfredsusilo@gmail.com
}

\begin{abstract}
ABSTRAK
Tanah merupakan salah satu hal yang harus diperhatian di dalam perencanaan pembangunan. Pada umumnya tanah memerlukan perbaikan dalam suatu proses konstruksi. Tetapi masih ditemui beberapa proyek pembangunan yang tidak menggunakan metode perbaikan tanah. Pada beberapa kasus perbaikan atau modifikasi tanah dapat meningkatkan daya dukung dan stabilitas tanah. Jika daya dukung meningkat maka jumlah tiang pancang yang digunakan dapat menjadi lebih efisien. Penurunan tanah akibat beban bangunan merupakan salah satu hal yang tidak dapat dihindari dalam konstruksi gedung bertingkat tinggi. Maka dibutuhkan metode perbaikan tanah yang bertujuan untuk menghindari kerusakan pada bangunan akibat penurunan tersebut. Pada penelitian ini dibatasi oleh metode prapembebanan dan pemancangan keliling. Salah satu contohnya adalah metode yang memanfaatkan timbunan untuk mempercepat proses pemampatan tanah. Metode perbaikan lain yang dimodifikasi adalah metode pemancangan keliling. Metode ini memanfaatkan tiang yang dipancang ke dalam tanah untuk mengurangi volume udara. Besar penurunan konsolidasi awal untuk tanah yang diperbaiki dengan timbunan serta pemancangan keliling masing-masing adalah 3,74 meter dengan timbunan setinggi 3 meter dan 5,2 meter untuk kedalaman tiang 50 meter. Perubahan angka pori berpengaruh terhadap besar penurunan konsolidasi. Nilai angka pori tanah yang dipadatkan akan menjadi lebih kecil sehingga besar penurunan konsolidasi yang dialami oleh tanah akan ikut berkurang. Dengan pembangunan lantai di bawah permukaan tanah sebagai lahan parkir maka tanah akan menerima beban parkiran sebesar 60 ton dari hasil perencanaan. Maka dari itu, nilai besar konsolidasi tanah setelah dikenai beban terhadap tanah yang tidak diperbaiki serta tanah yang diperbaiki dengan drainase vertikal berupa timbunan dan metode pemancangan keliling masing-masing adalah 0,26 meter, 0,213 meter dan 0,205 meter.
\end{abstract}

Kata kunci: : perbaikan tanah, stabilitas tanah, angka pori, tiang pancang, penurunan konsolidasi

\section{PENDAHULUAN}

Indonesia termasuk negara berkembang di Asia Tenggara menurut World Bank pada tahun 2015. Pada awal tahun 2000 hingga sekarang pembangunan gedung bertingkat serta infrastruktur semakin berkembang pesat di beberapa kota besar maupun daerah di Indonesia. Dengan itu para lulusan Teknik Sipil sangat dibutuhkan dalam merealisasikan pembangunan tersebut. Secara umum, Geoteknik merupakan ilmu yang mempelajari tentang tanah beserta permasalahannya. Dalam penerapannya, ilmu tersebut dapat dibagi atas beberapa bidang. Salah satunya adalah tentang perbaikan dan perkuatan tanah yang merupakan usaha yang dilakukan dengan tujuan untuk meningkatkan kualitas tanah, dimana stabilitas tanah tersebut akan mendukung sebuah struktur sehingga mampu menahan beban yang didistribusikan oleh bangunan yang berada di atasnya.

Menurut data dari Badan Pusat Statistik Indonesia menunjukan bahwa kepadatan penduduk di Indonesia dari tahun ke tahun relatif tidak berubah yang menjadikan pulau Jawa khususnya Jakarta sebagai wilayah terpadat di Indonesia dengan 149 juta jiwa atau sama dengan 57.12\% dari populasi di Indonesia. Hal tersebut menjadi salah satu faktor yang dapat mempercepat proses penurunan tanah. Dapat dilihat dari banyaknya pembangunan yang berbanding lurus dengan pertambahan kepadatan penduduk di suatu wilayah. Bangunan serta infrastruktur yang dibangun akan memberikan dampak settlement pada tanah yang dibangun di atasnya sehingga mempercepat proses penurunan konsolidasi tanah

Sebelum dilaksanakan suatu pembangunan gedung bertingkat, pada umumnya lapisan tanah akan dianalisis terlebih dahulu serta dilihat apakah diperlukan perbaikan tanah atau soil improvement. Hal tersebut yang menjadi salah satu 
kendala bagi para kontraktor dalam mengolah tanah lunak karena perbaikan tanahnya memerlukan waktu sehingga dapat merubah rencana awal pembangunan yang telah disusun sebelumnya.

Tanah adalah material yang terdiri dari agregat (butiran) mineral-mineral padat yang tidak tersementasi (terikat secara kimia) satu sama lain dan dari bahan-bahan organik yang telah melapuk (yang berpatikel padat) disertai dengan zat cair dan gas yang mengisi ruang-ruang kosong di antara partikel-partikel padat tersebut. Berdasarkan ASTM D42263 (2007) bahwa ukuran partikel, tanah dibagi menjadi empat jenis; kerikil (gravel), pasir (sand), lanau (silt), dan lempung (clay). Menurut Sistem Klasifikasi Unified, kerikil dan pasir disebut sebagai tanah berbutir kasar, sedangkan lanau dan lempung disebut sebagai tanah berbutir halus.

Atterberg memberikan cara untuk menggambarkan batas-batas konsistensi dari tanah berbutir halus dengan mempertimbangkan kandungan air tanah. Batas-batas tersebut adalah batas cair (liquid limit), batas plastis (plastic limit), dan batas susut (shrinkage limit). Pada dasarnya tanah mempunyai 4 kondisi, yaitu kondisi cair, kondisi plastis, kondisi semi padat dan kondisi padat. Batas antara kondisi cair ke plastis disebut batas cair dan batas antara kondisi plastis ke semi padat disebut batas plastis sedangkan batas antara semi padat ke padat disebut batas susut (shrinkage limit).

Ada tiga macam keadaan pada penurunan konsolidasi yang dialami oleh tanah yaitu Over Consolidated (OC) dimana istilah ini adalah tekanan pada suatu lapisan tanah pada waktu dahulu pernah mengalami pembebanan. Misalnya lapisan endapan, oleh sebab geologis endapan tersebut hilang, saehingga lapisan tanah tersebut pernah mengalami tekanan lebih tinggi dari pada tekanan yang berlaku di atasnya saat ini. Istilah lainnya adalah Normally Consolidated (NC) adalah menyatakan suatu lapisan tanah yang belum pernah mengalami tekanan di atasnya lebih tinggi dari pada tekanan yang berlaku saat ini. Berikutnya adalah Under Consolidated (UC) dimana istilah ini adalah dimana tegangan overburden saat ini belum mencapai maksimum saat pengambilan sampel tanah sedang berlangsung.

Umumnya penurunan konsolidasi terjadi dalam satu arah saja yaitu arah vertikal dari atas ke bawah, dikarenakan beban tambahan yang diterima dari arah horizontal dapat ditahan oleh tanah yang disekitarnya atau yang biasanya disebut dengan konsolidasi satu arah atau one dimensional consolidation. Dalam keadaan seperti ini, pengaliran air dalam tanah juga dilalui dalam arah vertikal.

Pemanfaatan perbaikan tanah dengan proses timbunan yaitu dengan meletakkan tanah urug di atas tanah dengan tujuan diharapkan agar tanah mengalami penurunan konsolidasi sebagai bagian dari proses pemampatan. Tanah timbunan yang dipakai menggunakan jenis tanah lempung agar memberikan pengaruh kenaikan tegangan yang signifikan pada tanah yang akan ditimbun di atasnya.

Metode perbaikan tanah pemancangan keliling digunakan dengan cara memanfaatkan tiang pancang yang dipasang di lahan sebagaimana proyek pembangunan akan berlangsung. Tiang pancang yang telah dipasang sifatnya adalah untuk memagari pergerakan tanah yang ada di dalamnya. Kemudian dilakukan pemasangan pondasi dari bangunan yang menyebabkan udara dalam tanah akan secara langsung terisi. Sehingga nilai angka pori (e) dalam tanah akan berkurang. Dengan itu, besar penurunan tanah akan berlangsung lebih kecil dari kondisi awal.

\section{METODOLOGI PENELITIAN}

\section{Data penyelidikan tanah}

Salah satu elemen penting dalam merencanakan perhitungan penurunan konsolidasi adalah dengan mengetahui kondisi tanah yang akan ditinjau. Maka data penyelidikan tanah sangat dibutuhkan dalam melakukan perencanaan. Data yang dapat digunakan berupa data dari hasil uji lapangan serta hasil uji laboratorium. Data hasil uji lapangan yaitu nilai N-SPT tanah yang digunakan untuk menentukan jenis tanah pada kedalaman tertentu. Contoh hasil uji laboratorium berupa parameter tanah dari uji konsolidasi serta berat jenis tanah yang diuji.

Data penyelidikan tanah yang digunakan merupakan sampel tanah yang berada pada lokasi proyek di Gedebage, Bandung, Jawa Barat. Uji Penyelidikan tanah adalah kegiatan untuk mengetahui daya dukung dan karateristik tanah serta kondisi geologi, seperti mengetahui susunan lapisan tanah/sifat tanah, mengetahui kekuatan lapisan tanah dalam rangka penyelidikan tanah dasar untuk keperluan pondasi bangunan, jalan, kepadatan dan daya dukung tanah serta mengetahui sifat korosivitas tanah.

\section{Data lapangan}

Pengujian hand boring dan SPT didasarkan atas ASTM D-1586, hasil dari pengujian ini adalah diskripsi susunan lapisan-lapisan tanah serta nilai SPT yang dinyatakan dalam N pukulan. Nilai SPT diperoleh yaitu pada tabung SPT ditekan tau dipukul sedalam $150 \mathrm{~mm}$ pada tanah tak terganggu sambil mencatat banyaknya pukulan yang diperlukan. Pengujian ini dilakukan bersamaan dengan pengambilan contoh tanah dan biasa dilakukan tiap 1.5 serta 2 meter kedalaman atau tiap pergantian jenis lapisan tanah. 


\section{Data laboratorium}

Pengujian ini menggunakan sampel tanah yang telah di ambil pada pekerjaan core drilling yaitu undistrubed sample / contoh tanah tidak terganggu. Uji laboratorium dilakukan untuk mengetahui sifat dan karakteristik tanah, Hasil dari uji laboratorium akan di korelasikan dengan hasil uji lapangan sehingga dapat didesain dimensi pondasi yang aman dan efisien.

Beberapa parameter tanah yang dibutuhkan dalam merencanakan besar penurunan konsolidasi dari hasil uji laboratorium yaitu:
a. Berat jenis
b. Specific Gravity
c. Angka pori
d. Saturasi
e. Kadar air
f. Indeks Plastisitas
g. Indeks Pemampatan

\section{Timbunan}

Timbunan dengan tanah urugan di atas tanah yang ditinjau akan memberikan beban sehingga menyebabkan adanya kenaikan tegangan efektif. Nilai kenaikan tegangan efektif tanah $\left(\Delta \sigma^{\prime}\right)$ akibat timbunan dapat diperoleh dengan persamaan:

$$
\Delta \sigma^{\prime}=2 \times I \times q 0
$$

dengan $\Delta \sigma=$ kenaikan tegangan, $\mathrm{I}=$ faktor pengaruh, $\mathrm{q}_{0}=$ beban timbunan

\section{Pemancangan}

Tiang pancang yang dipancangkan ke dalam tanah akan mengurangi besar volume udara dalam tanah yang menyebabkan nilai angka pori (e) semakin berkurang. Hal tersebut akan memberikan pengaruh bagi perubahan berat jenis tanah dengan persamaan korelasi sebagai berikut.

$$
\gamma=(G s+e) \times \frac{\gamma w}{(1+e)}
$$

dengan $\mathrm{\gamma}=$ berat jenis tanah, Gs = specific gravity, $\mathrm{\gamma}_{\mathrm{w}}=$ berat jenis air, $\mathrm{e}=$ angka pori

\section{Penurunan Konsolidasi}

Besar penurunan konsolidasi yang dialami oleh tanah dapat diperhitungkan dengan menggunakan korelasi angka pori dengan persamaan:

$$
S c=\frac{e 0-e 1}{1+e 0} \times H \times \Delta \sigma
$$

dengan $\mathrm{Sc}=$ besar penurunan konsolidasi, $\mathrm{e}_{0}=$ angka pori awal, $\mathrm{e}_{1}=$ angka pori akhir, $\mathrm{H}=$ kedalaman, $\Delta \sigma=$ kenaikan tegangan tanah

Perhitungan penurunan konsolidasi dengan keadaan tanah normally consolidated (NC) dapat dihitung dengan persamaan:

$$
S c=\frac{H}{1+e} \times C c \times \log \frac{\sigma_{0}+\Delta \sigma}{\sigma 0}
$$

dengan $\mathrm{Sc}=$ besar penurunan konsolidasi, $\mathrm{H}=$ kedalaman, $\mathrm{e}=$ angka pori, $\mathrm{Cc}=$ indeks kompresibilitas, $\sigma_{0}=$ tegangan awal tanah, $\Delta \sigma=$ kenaikan tegangan tanah 
Besar penurunan konsolidasi yang dialami oleh tanah akan menjadi keadaaan asli dari tanah dengan kedalaman lapisan tanah yang telah dimampatkan. Selanjutnya perencanaan besar penurunan konsolidasi akan dihitung dengan adanya penambahan beban dari basement yang difungsikan sebagai lahan parkir sebesar 60 ton.

\section{ANALISIS DATA}

\section{Perbaikan tanah dengan timbunan}

Timbunan yang dipakai dengan ketinggian 3 meter serta berat jenis tanah timbunan adalah sebesar 1,65 ton $/ \mathrm{m}^{3}$. Besar penurunan konsolidasi yang dialami oleh tanah akibat proses pemampatan dengan timbunan dapat dilihat pada tabel 1 dan 2.

Tabel 1. Perhitungan parameter tanah akibat timbunan

\begin{tabular}{|r|r|r|l|r|r|r|r|r|r|}
\hline $\mathrm{Z}(\mathrm{m})$ & Kumulatif & $\begin{array}{l}\text { Kum } \\
+\mathrm{Hdr}\end{array}$ & $\begin{array}{l}\text { Type } \\
\text { of Soil }\end{array}$ & $\begin{array}{l}\gamma_{\text {sat }} \\
\left(\mathrm{T} / \mathrm{m}^{3}\right)\end{array}$ & $\begin{array}{l}\text { y' } \\
\left(\mathrm{T} / \mathrm{m}^{3}\right)\end{array}$ & $\begin{array}{l}\sigma_{0}^{\prime} \\
\left(\mathrm{T} / \mathrm{m}^{2}\right)\end{array}$ & $\mathrm{e}$ & a & b \\
\hline 5 & 5 & 5 & $\mathrm{CH}$ & 1,422 & 0,422 & 1,055 & 2,01 & 20,33 & 29,67 \\
\hline 4 & 9 & 7 & $\mathrm{MH}$ & 1,122 & 0,122 & 2,354 & 4,45 & 20,33 & 29,67 \\
\hline 6 & 15 & 12 & $\mathrm{MH}$ & 1,054 & 0,054 & 2,76 & 5,114 & 20,33 & 29,67 \\
\hline 4 & 19 & 17 & $\mathrm{MH}$ & 1,187 & 0,187 & 3,296 & 3,7 & 20,33 & 29,67 \\
\hline 4 & 23 & 21 & $\mathrm{MH}$ & 1,229 & 0,229 & 4,128 & 2,878 & 20,33 & 29,67 \\
\hline 4 & 27 & 25 & $\mathrm{MH}$ & 1,161 & 0,161 & 4,908 & 3,841 & 20,33 & 29,67 \\
\hline 3 & 30 & 28,5 & $\mathrm{MH}$ & 1,073 & 0,073 & 5,3395 & 5,3 & 20,33 & 29,67 \\
\hline
\end{tabular}

Tabel 2. Perhitungan konsolidasi akibat timbunan

\begin{tabular}{|r|r|r|r|r|r|r|r|}
\hline \multicolumn{1}{|l|}{$\alpha_{1}$} & \multicolumn{1}{|c|}{$\alpha_{2}$} & \multicolumn{1}{|l|}{$\Delta \sigma^{\prime}\left(\mathrm{T} / \mathrm{m}^{2}\right)$} & \multicolumn{1}{l|}{ Wc $(\%)$} & \multicolumn{1}{l|}{ LL } & \multicolumn{1}{l|}{ Cc } & \multicolumn{1}{l|}{ Sc $(\mathrm{m})$} \\
\hline 0,067283 & 1,403845 & 1,569322 & 15,53629 & 62,26 & 73,55 & 0,335 & 0,6659 \\
\hline 0,092596 & 1,339105 & 1,566836 & 15,51168 & 152,26 & 179,12 & 1,074 & 0,6938 \\
\hline 0,148791 & 1,186461 & 1,5524 & 15,36876 & 166,86 & 222,4 & 1,377 & 1,1047 \\
\hline 0,192568 & 1,050489 & 1,524096 & 15,08855 & 125,13 & 160,09 & 0,941 & 0,5978 \\
\hline 0,218304 & 0,954864 & 1,491766 & 14,76848 & 116,64 & 137,28 & 0,781 & 0,5322 \\
\hline 0,236536 & 0,870613 & 1,452354 & 14,3783 & 131,09 & 167,89 & 0,995 & 0,4886 \\
\hline 0,247219 & 0,805509 & 1,413524 & 13,99389 & 173,13 & 200,1 & 1,221 & 0,3249 \\
\hline
\end{tabular}

Besar penurunan konsolidasi sebagai akibat dari pemampatan dengan metode timbunan adalah sebesar 3,742 meter dengan kedalaman 30 meter.

\section{Perbaikan tanah dengan pemancangan keliling}

Besar penurunan konsolidasi dari tanah akibat dari proses pemampatan dengan metode pemancangan keliling dapat dilihat pada tabel 3 dan 4 . 
Tabel 3. Parameter tanah akibat pemancangan keliling

\begin{tabular}{|r|r|l|l|r|r|r|r|r|r|}
\hline Lapisan & $\mathrm{Z}(\mathrm{m})$ & $\mathrm{e}$ & \multicolumn{1}{l|}{$\mathrm{n}$} & $\mathrm{V}\left(\mathrm{m}^{3}\right)$ & $\mathrm{Vv}\left(\mathrm{m}^{3}\right)$ & $\mathrm{V}$ tiang $\left(\mathrm{m}^{3}\right)$ & $\mathrm{Vs}\left(\mathrm{m}^{3}\right)$ & $\mathrm{Vv}^{\prime}\left(\mathrm{m}^{3}\right)$ & $\mathrm{e}^{\prime}$ \\
\hline 1 & 5 & 2,01 & 0,667774 & 50000 & 33388,7 & 5887,5 & 16611,296 & 27501,2 & 1,656 \\
\hline 2 & 4 & 4,45 & 0,816514 & 40000 & 32660,55 & 4710 & 7339,4495 & 27950,55 & 3,808 \\
\hline 3 & 6 & 5,11 & 0,836334 & 60000 & 50180,03 & 7065 & 9819,9673 & 43115,03 & 4,391 \\
\hline 4 & 4 & 3,7 & 0,787234 & 40000 & 31489,36 & 4710 & 8510,6383 & 26779,36 & 3,147 \\
\hline 5 & 4 & 2,88 & 0,742268 & 40000 & 29690,72 & 4710 & 10309,278 & 24980,72 & 2,423 \\
\hline 6 & 4 & 3,84 & 0,793388 & 40000 & 31735,54 & 4710 & 8264,4628 & 27025,54 & 3,27 \\
\hline 7 & 18 & 5,3 & 0,84127 & 180000 & 151428,6 & 21195 & 28571,429 & 130233,6 & 4,558 \\
\hline 8 & 5 & 4,42 & 0,815498 & 50000 & 40774,91 & 5887,5 & 9225,0923 & 34887,41 & 3,782 \\
\hline
\end{tabular}

Tabel 4. Perhitungan konsolidasi akibat pemancangan keliling

\begin{tabular}{|c|r|r|r|r|r|r|}
\hline \multicolumn{1}{|c|}{$\mathrm{\gamma}^{\prime}$} & \multicolumn{1}{c|}{$\begin{array}{l}\sigma^{\prime} 0 \\
\left(\mathrm{~T} / \mathrm{m}^{2}\right)\end{array}$} & $\begin{array}{l}\Delta \sigma^{\prime} \\
\left(\mathrm{T} / \mathrm{m}^{2}\right)\end{array}$ & Wc $(\%)$ & \multicolumn{1}{l|}{ LL } & \multicolumn{1}{l|}{ Cc } & \multicolumn{1}{l|}{$\mathrm{Sc}(\mathrm{m})$} \\
\hline 0,422 & 2,11 & 14,11 & 62,26 & 73,55 & 0,3349 & 0,558441 \\
\hline 0,122 & 2,598 & 10,088 & 152,26 & 179,12 & 1,0741 & 0,615405 \\
\hline 0,054 & 2,922 & 14,724 & 166,86 & 222,4 & 1,3771 & 1,19696 \\
\hline 0,187 & 3,67 & 10,348 & 125,13 & 160,09 & 0,9408 & 0,528155 \\
\hline 0,229 & 4,586 & 10,516 & 116,64 & 137,28 & 0,7811 & 0,472448 \\
\hline 0,161 & 5,23 & 10,244 & 131,09 & 167,89 & 0,9954 & 0,439282 \\
\hline 0,073 & 6,544 & 44,514 & 173,13 & 200,1 & 0,433 & 1,251163 \\
\hline 0,205 & 7,569 & 13,025 & 162,52 & 181,05 & 0,307 & 0,139537 \\
\hline
\end{tabular}

Besar penurunan konsolidasi sebagai akibat dari pemampatan dengan metode pemancangan keliling adalah sebesar 5,2 meter hingga kedalaman tiang 50 meter.

\section{HASIL DAN PERBANDINGAN}

\section{Perbandingan angka pori}

Pada tanah yang diperbaiki atau dimampatkan dapat merubah nilai parameter tanah salah satunya adalah nilai angka pori. Angka pori akan berpengaruh pada besar penurunan konsolidasi yang dialami oleh tanah. Berikut adalah hasil perbandingan angka pori pada tanah yang belum diperbaiki serta yang diperbaiki dengan timbunan dan pemancangan keliling.

Tabel 5. Perbandingan perubahan angka pori dalam tanah

\begin{tabular}{|c|c|c|c|c|c|c|}
\hline $\begin{array}{c}\text { Kedalaman } \\
(\mathrm{m})\end{array}$ & Lapisan & e Awal & $\begin{array}{c}\mathrm{e} \\
\text { Pancang }\end{array}$ & $\begin{array}{c}\mathrm{e} \\
\text { Timbunan }\end{array}$ & \multicolumn{2}{|c|}{ Perbedaan $(\%)$} \\
\hline 5 & 1 & 2,01 & 1,656 & 1,609 & 17,612 & 19,95 \\
\hline 4 & 2 & 4,45 & 3,808 & 3,505 & 14,427 & 21,236 \\
\hline 6 & 3 & 5,114 & 4,391 & 3,988 & 14,138 & 22,018 \\
\hline 4 & 4 & 3,7 & 3,147 & 2,998 & 14,946 & 18,973 \\
\hline 4 & 5 & 2,878 & 2,423 & 2,362 & 15,81 & 17,929 \\
\hline 4 & 6 & 3,841 & 3,27 & 3,25 & 14,866 & 15,387 \\
\hline 3 & 7 & 5,3 & 4,558 & 4,618 & 14 & 12,868 \\
\hline
\end{tabular}




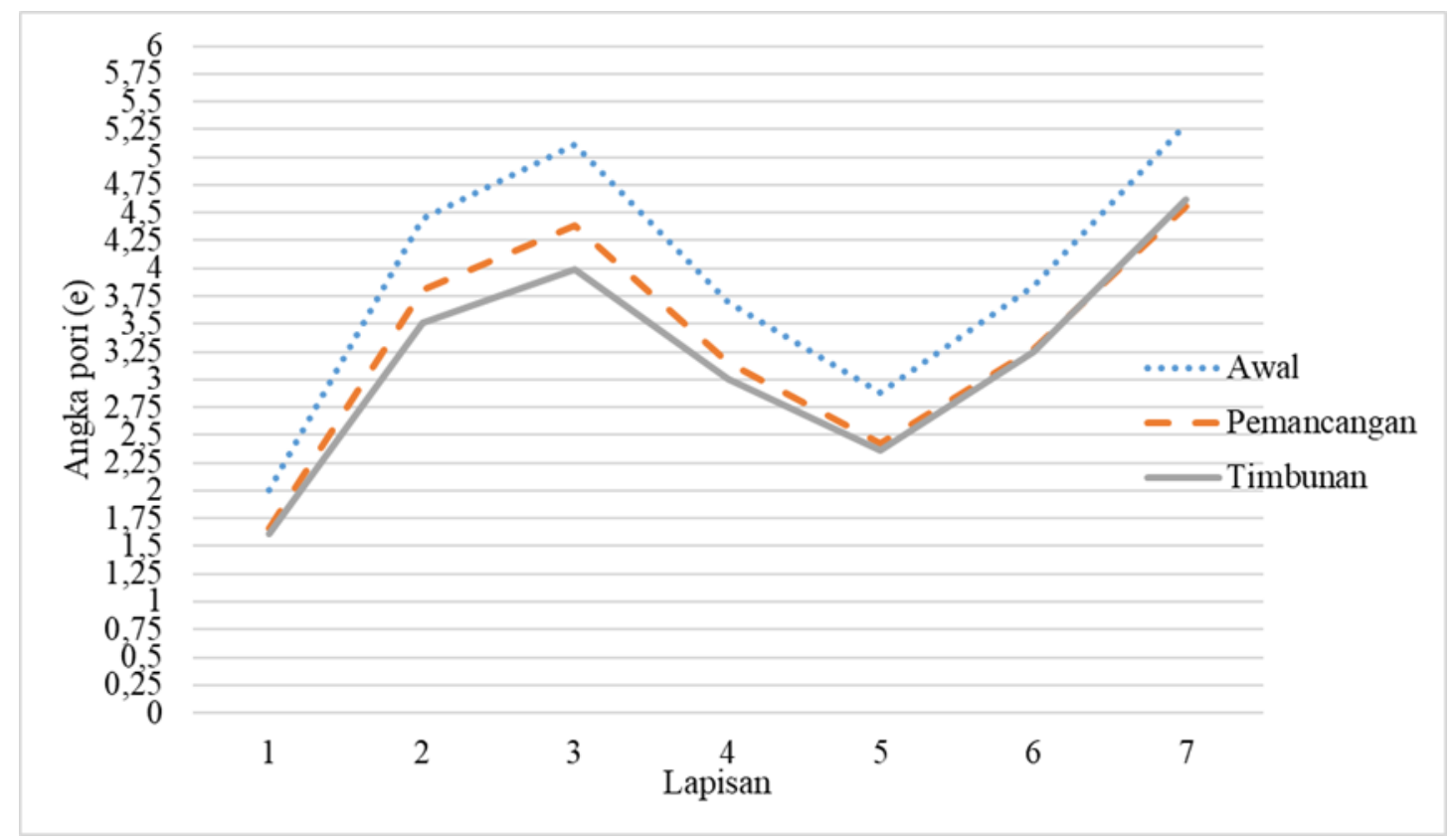

Gambar 1. Perbandingan perubahan angka pori

\section{Penurunan konsolidasi akibat beban parkiran 60 ton}

Perencanaan beban parkiran sebesar 60 ton mengacu pada SNI 1727:2013 tentang pembebanan gedung bertingkat bahwa beban hidup lahan parkir adalah sebesar 0,4 ton $/ \mathrm{m}^{2}$.

\section{Tanah yang belum diperbaiki}

Hasil perencanaan besar penurunan konsolidasi akibat beban parkiran yang dihitung dengan persamaan 4 dapat dilihat pada tabel 5 dan 6 .

Tabel 6. Parameter tanah hasil laboratorium

\begin{tabular}{|c|c|c|c|c|c|c|}
\hline Lapisan & $\mathrm{Z}(\mathrm{m})$ & $\mathrm{e}$ & $\mathrm{G}$ & $\mathrm{\gamma}_{\mathrm{w}}\left(\mathrm{t} / \mathrm{m}^{3}\right)$ & $\mathrm{\gamma}_{\text {sat }}\left(\mathrm{t} / \mathrm{m}^{3}\right)$ & $\mathrm{\gamma}\left(\mathrm{t} / \mathrm{m}^{3}\right)$ \\
\hline 1 & 5 & 2,01 & 2,639 & 1 & 1,422 & 0,422 \\
\hline 2 & 4 & 4,45 & 2,924 & 1 & 1,122 & 0,122 \\
\hline 3 & 6 & 5,114 & 2,416 & 1 & 1,054 & 0,054 \\
\hline 4 & 4 & 3,7 & 2,478 & 1 & 1,187 & 0,187 \\
\hline 5 & 4 & 2,878 & 2,2 & 1 & 1,229 & 0,229 \\
\hline 6 & 4 & 3,841 & 2,432 & 1 & 1,161 & 0,161 \\
\hline 7 & 3 & 5,3 & 2,476 & 1 & 1,073 & 0,073 \\
\hline
\end{tabular}


Tabel 7. Hasil perhitungan penurunan konsolidasi pada tanah yang belum diperbaiki

\begin{tabular}{|r|c|r|c|r|r|r|r|r|r|}
\hline $\mathrm{H}(\mathrm{m})$ & \multicolumn{1}{l|}{$\mathrm{Cc}$} & \multicolumn{1}{|c|}{$\mathrm{e}^{\prime}$} & $\mathrm{G}$ & $\begin{array}{l}\mathrm{\gamma} \text { sat } \\
\left(\mathrm{T} / \mathrm{m}^{3}\right)\end{array}$ & $\begin{array}{l}\mathrm{\gamma}^{\prime} \\
\left(\mathrm{T} / \mathrm{m}^{3}\right)\end{array}$ & $\begin{array}{l}\sigma_{0}^{\prime} \\
\left(\mathrm{T} / \mathrm{m}^{2}\right)\end{array}$ & $\begin{array}{l}\Delta \sigma^{\prime} \\
\left(\mathrm{T} / \mathrm{m}^{2}\right)\end{array}$ & $\mathrm{Cc}$ & $\mathrm{Sc}(\mathrm{m})$ \\
\hline 5 & 0,3349 & 2,01 & 2,639 & 1,422 & 0,422 & 1,055 & 1,146 & 0,335 & 0,1777 \\
\hline 4 & 1,0741 & 4,45 & 2,924 & 1,122 & 0,122 & 2,354 & 0,354 & 1,074 & 0,0447 \\
\hline 6 & 1,3771 & 5,114 & 2,416 & 1,054 & 0,054 & 2,76 & 0,127 & 1,377 & 0,0192 \\
\hline 4 & 0,9408 & 3,7 & 2,478 & 1,187 & 0,187 & 3,296 & 0,079 & 0,941 & 0,0088 \\
\hline 4 & 0,7811 & 2,878 & 2,2 & 1,229 & 0,229 & 4,128 & 0,054 & 0,781 & 0,0058 \\
\hline 4 & 0,9954 & 3,841 & 2,432 & 1,161 & 0,161 & 4,908 & 0,039 & 0,995 & 0,0028 \\
\hline 3 & 0,433 & 5,3 & 2,476 & 1,073 & 0,073 & 5,3395 & 0,032 & 1,221 & 0,0012 \\
\hline
\end{tabular}

Besar penurunan konsolidasi yang dialami oleh tanah tanpa perbaikan yang didapat dari hasil perencanaan pembebanan adalah sebesar 0,26 meter dengan kedalaman 30 meter.

\section{Tanah yang diperbaiki dengan timbunan}

Hasil perencanaan besar penurunan konsolidasi akibat beban parkiran pada tanah yang sebelumnya dimampatkan dengan timbunan dapat dilihat pada tabel 7, 8 dan 9.

Tabel 8. Perubahan angka pori

\begin{tabular}{|r|r|r|r|r|r|r|}
\hline \multicolumn{1}{|c|}{$\mathrm{H}(\mathrm{m})$} & $\sigma_{0}^{\prime}(\mathrm{T} / \mathrm{m} 2)$ & \multicolumn{1}{|l|}{$\Delta \sigma^{\prime}\left(\mathrm{T} / \mathrm{m}^{2}\right)$} & $\mathrm{Cc}$ & \multicolumn{1}{l|}{$\mathrm{e}$} & $\mathrm{e}$ & $\mathrm{e}^{\prime}$ \\
\hline 5 & 1,055 & 15,5362873 & 0,335 & 0,401 & 2,01 & 1,609 \\
\hline 4 & 2,354 & 15,5116813 & 1,074 & 0,945 & 4,45 & 3,505 \\
\hline 6 & 2,76 & 15,3687555 & 1,377 & 1,126 & 5,114 & 3,988 \\
\hline 4 & 3,296 & 15,0885485 & 0,941 & 0,702 & 3,7 & 2,998 \\
\hline 4 & 4,128 & 14,7684802 & 0,781 & 0,516 & 2,878 & 2,362 \\
\hline 4 & 4,908 & 14,3783016 & 0,995 & 0,591 & 3,841 & 3,25 \\
\hline 3 & 5,3395 & 13,9938864 & 1,221 & 0,682 & 5,3 & 4,618 \\
\hline
\end{tabular}

Tabel 9. Perubahan berat jenis tanah akibat timbunan

\begin{tabular}{|c|c|c|c|c|c|}
\hline $\mathrm{H}(\mathrm{m})$ & $\mathrm{Cc}$ & $\Delta \mathrm{e}$ & $\mathrm{e}^{\prime}$ & $\mathrm{G}$ & Ysat $\left(T / \mathrm{m}^{3}\right)$ \\
\hline 5 & 0,335 & 0,401 & 1,609 & 2,639 & 1,628 \\
\hline 4 & 1,074 & 0,945 & 3,505 & 2,924 & 1,427 \\
\hline 6 & 1,377 & 1,126 & 3,988 & 2,416 & 1,284 \\
\hline 4 & 0,941 & 0,702 & 2,998 & 2,478 & 1,37 \\
\hline 4 & 0,781 & 0,516 & 2,362 & 2,2 & 1,357 \\
\hline 4 & 0,995 & 0,591 & 3,25 & 2,432 & 1,337 \\
\hline 3 & 1,221 & 0,682 & 4,618 & 2,476 & 1,263 \\
\hline
\end{tabular}


Tabel 10. Besar penurunan konsolidasi tanah akibat timbunan

\begin{tabular}{|c|c|c|c|c|c|c|c|}
\hline $\mathrm{H}(\mathrm{m})$ & $\mathrm{Cc}$ & $\mathrm{e}^{\prime}$ & G & \begin{tabular}{|l|}
$\mathrm{y}^{\prime}$ \\
$(\mathrm{T} / \mathrm{m} 3)$ \\
\end{tabular} & $\begin{array}{l}\sigma_{0}^{\prime} \\
(\mathrm{T} / \mathrm{m} 2)\end{array}$ & $\begin{array}{l}\Delta \sigma^{\prime} \\
(\mathrm{T} / \mathrm{m} 2)\end{array}$ & $\mathrm{Sc}(\mathrm{m})$ \\
\hline 5 & 0,335 & 1,609 & 2,639 & 0,628 & 1,57 & 1,146 & 0,1528 \\
\hline 4 & 1,074 & 3,505 & 2,924 & 0,427 & 3,994 & 0,354 & 0,0352 \\
\hline 6 & 1,377 & 3,988 & 2,416 & 0,284 & 5,7 & 0,127 & 0,0159 \\
\hline 4 & 0,941 & 2,998 & 2,478 & 0,37 & 7,292 & 0,079 & 0,0044 \\
\hline 4 & 0,781 & 2,362 & 2,2 & 0,357 & 8,746 & 0,054 & 0,0025 \\
\hline 4 & 0,995 & 3,25 & 2,432 & 0,337 & 10,134 & 0,039 & 0,0016 \\
\hline 3 & 1,221 & 4,618 & 2,476 & 0,263 & 11,2025 & 0,032 & 0,0008 \\
\hline
\end{tabular}

Dari hasil perencanaan, besar penurunan konsolidasi yang dialami oleh tanah setelah proses pemampatan dengan timbunan adalah sebesar 0,21 meter dengan kedalaman 30 meter.

\section{Tanah yang diperbaiki dengan pemancangan keliling}

Hasil perencanaan besar penurunan konsolidasi yang dialami tanah setelah pemampatan dengan metode pemancangan keliling dapat dilihat pada tabel 10 dan 11.

Tabel 11. Perubahan angka pori

\begin{tabular}{|c|c|c|c|c|c|c|c|c|}
\hline $\mathrm{Z}(\mathrm{m})$ & $\mathrm{e}$ & $\mathrm{n}$ & $\mathrm{V}\left(\mathrm{m}^{3}\right)$ & $\begin{array}{l}\mathrm{V}_{\mathrm{v}} \\
\left(\mathrm{m}^{3}\right)\end{array}$ & $\begin{array}{l}\mathrm{V} \\
\left(\mathrm{m}^{3}\right)\end{array}$ & $\mathrm{V}_{\mathrm{s}}\left(\mathrm{m}^{3}\right)$ & $\begin{array}{l}\mathrm{V}_{\mathrm{v}^{\prime \prime}} \\
\left(\mathrm{m}^{3}\right)\end{array}$ & $\mathrm{e}^{\prime}$ \\
\hline 5 & 2,01 & 0,668 & 50000 & 33400 & 5887,5 & 16600 & 27512,5 & 1,657 \\
\hline 4 & 4,45 & 0,817 & 40000 & 32680 & 4710 & 7320 & 27970 & 3,821 \\
\hline 6 & 5,11 & 0,836 & 60000 & 50160 & 7065 & 9840 & 43095 & 4,38 \\
\hline 4 & 3,7 & 0,787 & 40000 & 31480 & 4710 & 8520 & 26770 & 3,142 \\
\hline 4 & 2,88 & 0,742 & 40000 & 29680 & 4710 & 10320 & 24970 & 2,42 \\
\hline 4 & 3,84 & 0,793 & 40000 & 31720 & 4710 & 8280 & 27010 & 3,262 \\
\hline 18 & 5,3 & 0,841 & 180000 & 151380 & 21195 & 28620 & 130185 & 4,549 \\
\hline 5 & 4,42 & 0,815 & 50000 & 40750 & 5887,5 & 9250 & 34862,5 & 3,769 \\
\hline
\end{tabular}

Tabel 12. Penurunan konsolidasi tanah akibat pemancangan

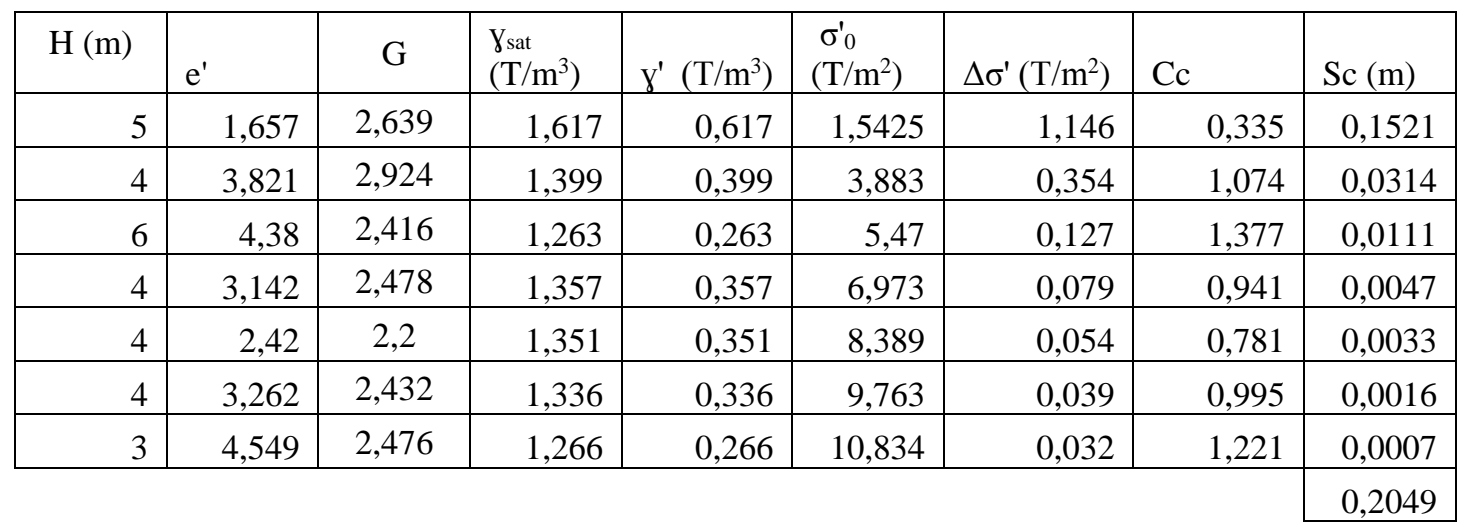

Dari hasil perencanaan, besar penurunan tanah setelah proses pemampatan dengan metode pemancangan keliling adalah sebesar 0,204 meter dengan kedalaman 30 meter. 


\section{Perbandingan penurunan konsolidasi}

Perbandingan hasil penurunan konsolidasi yang dialami oleh tanah tanpa perbaikan serta yang diperbaiki dengan timbunan dan pemancangan keliling dapat dilihat pada tabel 12 kemudian diproyeksikan ke dalam grafik pada gambar 1.

Tabel 13. Perbandingan besar penurunan konsolidasi

\begin{tabular}{|c|c|c|c|c|}
\cline { 3 - 5 } \multicolumn{2}{c|}{} & \multicolumn{3}{c|}{ Sc $(\mathrm{m})$} \\
\hline Kedalaman $(\mathrm{m})$ & $\mathrm{Z}(\mathrm{m})$ & Data Lab & Preloading & Pemancangan Keliling \\
\hline 5 & 5 & 0,1777 & 0,1528 & 0,1522 \\
\hline 9 & 4 & 0,2224 & 0,188 & 0,1837 \\
\hline 15 & 6 & 0,2416 & 0,2039 & 0,1948 \\
\hline 19 & 4 & 0,2504 & 0,2083 & 0,1995 \\
\hline 23 & 4 & 0,2562 & 0,2108 & 0,2028 \\
\hline 27 & 4 & 0,259 & 0,2124 & 0,2044 \\
\hline 30 & 3 & 0,2602 & 0,2132 & 0,2051 \\
\hline
\end{tabular}

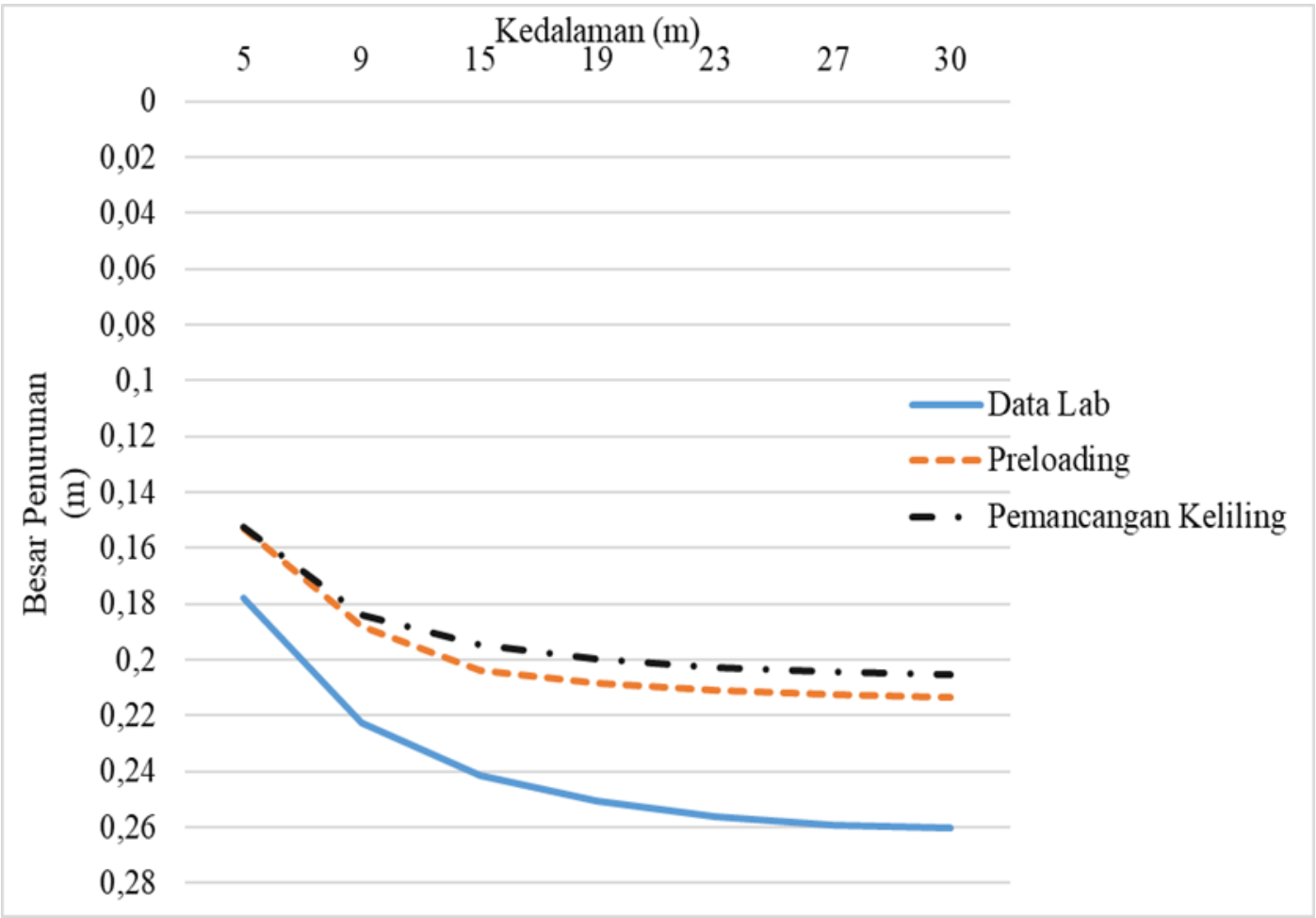

Gambar 2. Grafik perbandingan penurunan konsolidasi 


\section{KESIMPULAN DAN SARAN}

\section{Kesimpulan}

Pemampatan dengan metode pemancangan keliling memberikan hasil yang paling besar untuk penurunan konsolidasi yang dialami oleh tanah. Maka dengan itu, akan direncanakan pembangunan basement yang difungsikan sebagai lahan parkir yang kemudian akan berpengaruh pada perhitungan selanjutnya. Berdasarkan SNI 1727:2013 bahwa beban yang diterima lahan parkir adalah sebesar 0,4 ton/m2 maka diambil beban sebesar 60ton yang disalurkan ke tanah hingga mencapai kenaikan besar tegangan berupa $10 \%$ dari beban yang diberikan.

Penggunaan metode perbaikan pemancangan keliling pada tanah akan memberikan hasil yang lebih efektif dalam mengurangi besar penurunan konsolidasi yang dialami oleh tanah akibat beban parkiran. Dengan itu, dapat disimpulkan bahwa jenis tanah yang menggunakan perbaikan tanah metode pemancangan keliling akan efektivitas yang paling tinggi jika digunakan pada jenis tanah yang dipakai oleh peneliti.

Tanah hasil perbaikan menggunakan metode pemancangan keliling memberikan perencanaan penurunan konsolidasi yang paling kecil dengan adanya korelasi dengan nilai angka pori (void ratio).

\section{Saran}

Dengan adanya beberapa kasus pada pembangunan bertingkat tinggi, para perencana mendesain gedung tersebut tanpa adanya perbaikan tanah terlebih dahulu maka dapat disarankan apabila tanah dapat dilakukan perbaikan terlebih dahulu untuk meningkatkan stabilitas tanah.

Adanya korelasi void ratio dengan penurunan konsolidasi yang saling berhubungan. maka perbaikan tanah menjadi opsi yang terbaik sebelum pelaksanaan pembangunan yang bertujuan untuk memampatkan tanah untuk mengurangi kandungan air dan udara dalam tanah.

Pemanfaatan tanah dengan menggunakan metode perbaikan pemancangan keliling juga disarankan karena bertujuan untuk mengurangi besar penurunan konsolidasi tanah setelah proses pembangunan berlangsung.

\section{DAFTAR PUSTAKA}

ASTM Standard D-653-14. Standard Terminology Relating to Soil, Rock, and Contained Fluids. ASTM International, West Conshohocken, PA.

Bowles, Joseph E. (1982). Foundation Analysis and Design. Japan: McGraw-Hill.

Bowles, J.E. (1997). Foundation Analysis and Design International Fifth Edition. The McGraw-Hill Companies.

Chai, Jin-Chun, et al. (2001). SimpleMethod of modeling PVD improved subsoil. Journal of Geotechnical and Geoenvironmental Engineering, 965-972.

Das, Braja M. (2011). Principles of Geotechnical Engineering 7th edition. California: Thomson Learning.

Hardiyatmo, H.C. (2002). Teknik Pondasi I. Edisi Kedua. Beta Offset. Yogyakarta.

Holtz, Robert D and William D Kovacs. (1981). An Introduction to Geotechnical Engineering edition 2nd. Prentice Hall Inc Englewood Cliffs, New Jersey.

Kovacs, W.D., Holtz, R. (1981). An Introduction to Geotechnical Engineering. Canada: Prentice-Hill.

SNI 1727-2013. Peraturan Pembebanan Indonesia untuk Gedung dan Bangunan Lain.

Sosarodarsono, S. dan Nakazawa, K., 1983, Mekanika Tanah dan Teknik Pondasi. PT Pradnya Paramita, Jakarta. Wahyudi, Herman. (1999). Daya Dukung Pondasi Dalam. Surabaya: ITS Press. 